\title{
COMPREHENSIVE INCOME AND STOCK PRICE: THE CASE OF THE ENERGY INDUSTRY
}

\author{
Przemysław Poniatowski \\ University of Economics in Katowice \\ e-mail: przemyslaw.poniatowski@edu.uekat.pl
}

ORCID: 0000-0001-5959-0744

(C) 2021 Przemysław Poniatowski

This work is licensed under the Creative Commons Attribution-ShareAlike 4.0 International License. To view a copy of this license, visit http://creativecommons.org/licenses/by-sa/4.0/

Quote as: Poniatowski, P. (2021). Comprehensive income and stock price: The case of the energy industry. Financial Sciences, 26(1).

DOI: $10.15611 /$ fins.2021.1.05

JEL Classification: M41

\begin{abstract}
Financial results are the main source of information for investors on the stock market. The International Accounting Standards Board has been changing the basic rules regarding a shift from net income to comprehensive income as the main picture of the financial performance of a business. Up to now net income has been frequently researched for usefulness in financial analysis and its association with market returns and the stock price. The results of previous research are not consistent. Comprehensive income has been rarely analysed in this aspect. The article examines the relation between comprehensive income and stock price of the energy industry companies listed on the Warsaw Stock Exchange in the period 2010-2019. The author showed the theoretical and legal aspects of comprehensive income and analysed its influence on the stock price and market returns, using a quantitative approach.
\end{abstract}

Keywords: comprehensive income, stock price, statement of comprehensive income, clean surplus.

\section{Introduction}

The main goal of financial reporting is to provide financial information about an entity, that is useful for existing or potential investors, lenders and other creditors in making decisions (International Accounting Standards Board, 2020). Stock market investors, in their decision-making process, rely on financial information from the financial statements (Arkan, 2016; Szyszka, 2002). Measuring company performance and the financial position of a business is a major concern for a user of accounting information (Kanagaretnam, Mathieu, \& Shehata, 2009).

There are many views as to the main goal of running a business. According to neoclassical economics, profit is the main purpose. Economists say it is the prime 
mover or energizer of the capitalistic economy (McConnell, Brue, \& Flynn, 2009, p. 284). The ways of measuring and presenting company results have an important impact on users' decisions (Frendzel, \& Szychta, 2014). In accounting there are two main concepts defining the measurement of financial results (income) of a company in a specified period (Bek-Gaik, 2013, Newberry, 2003):

- as a measure of the performance of an enterprise and its management;

- as a change of investor wealth.

The first concept assumes that the economic results of a company are connected with the decisions of management and economic processes associated with that. This is a measurement of a company related to the dirty surplus accounting concept. Some "dirty surplus accounting flows" are shown directly in shareholders' equity and kept out of earnings (Wang, Buijink, \& Eken, 2006).

The second concept, associated with clean surplus accounting, assumes that income should measure all changes in the economic value of a business entity resulting from all activities and circumstances, except those arising from investments by and distributions to owners. This result is measured as comprehensive income.

Comprehensive income is defined as the change in equity of a business enterprise during a period from transactions and other events and circumstances from nonowner sources (FASB Concepts Statement No. 6..., 1985). It includes all changes in equity during a period, except those resulting from investments by owners and distributions to owners.

As stated in International Accounting Standard 1 (IAS 1), total comprehensive income includes all elements of profit and loss and those of other comprehensive income, it also comprises items of income and expenditure (including reclassification adjustments) that are not recognized in profit or loss as required or permitted by IFRSs. According to IAS 1, the components of other comprehensive income include:

- changes in revaluation surplus;

- remeasurements of defined benefit plans;

- gains and losses arising from translating the financial statements of a foreign operation;

- gains and losses from investments in equity instruments designated at fair value through other comprehensive income;

- gains and losses on financial assets measured at fair value through other comprehensive income;

- the effective portion of gains and losses on hedging instruments in a cash flow hedge, and the gains and losses on hedging instruments that hedge investments in equity instruments measured at fair value through other comprehensive income;

- for particular liabilities designated as at fair value through profit or loss, the amount of the change in fair value that is attributable to changes in the liability's credit risk; 
- changes in the value of the time value of options when separating the intrinsic value and time value of an option contract and designating as the hedging instrument only the changes in the intrinsic value;

- changes in the value of the forward elements of forward contracts when separating the forward element and spot element of a forward contract and designating as the hedging instrument only the changes in the spot element, and changes in the value of the foreign currency basis spread of a financial instrument when excluding it from the designation of that financial instrument as the hedging instrument;

- insurance finance income and expenses from contracts issued within the scope of IFRS 17 Insurance Contracts excluded from profit or loss when total insurance finance income or expenses is disaggregated to include in profit or loss an amount determined by a systematic allocation, or by an amount that eliminates accounting mismatches with the finance income or expenses arising on the underlying items; - finance income and expenses from reinsurance contracts held excluded from profit or loss when total reinsurance finance income or expenses is disaggregated to include in profit or loss an amount determined by a systematic allocation.

Those categories extend net income by capital changes which are the difference between net income and comprehensive income.

The International Accounting Standards Board (IASB) has been changing the basic rules regarding a shift from net income to comprehensive income as the main picture of the financial performance of a business, which shows the effectiveness of business activities. The implementation of the revised IAS 1 Presentation of Financial Statement in 2009 has obligated companies using the International Financial Reporting Standards to show comprehensive income. Nevertheless, financial results, defined as net income, are still being used as an indicator of the earnings (Rówińska, 2019).

According to the definition and international accounting standards, comprehensive income, and not net income, show the full picture of the situation of the company. It includes all changes in equity and shows the entire view of the financial performance and value of the company, as well as improves the ability to predict future earnings and cash flows. Using comprehensive income should enable investors to estimate the value of the given firm (Kanagaretnam, Mathieu and Shehata, 2009), which indicates the market value and stock price.

The association between earnings, market returns and stock price has been researched before, mostly considering net income as a measurement of earnings. The comprehensive income concept was also included in the research, again with comparison with net income. In this article, author assumed that comprehensive income is a measurement of financial performance, which is an innovative concept in this kind of research in the Polish context.

The article aims to check if reported earnings - described as comprehensive income - are associated with the market returns and the stock price, and whether it affects those categories. 


\section{Literature review}

The influence of company results, especially earnings (measured as net income or comprehensive income) on stock price and market returns, has been researched by many economists. Ball and Brown (1968) showed that there is a relation between earnings and stock price. Lev (1989) stated that earnings appear to be used by investors, but on the other hand, the extent of their usefulness is limited, and the correlation between stock price and stock return is weak. Har and Ghafar (2015) researched the impact of earnings (financial indicators) on stock return, and found them useful in predicting stock returns. Lipe (1990) showed that changes in prices are correlated with future earnings. Isidro and Dias (2017) pointed out that the correlation between stock price and reported earnings varies in different firms.

In their research, various authors also indicated earnings as comprehensive income or compared net income and comprehensive income. Dhaliwal, Subramanyam and Trezevant (1999) could not find evidence that comprehensive income has more association than net income, nevertheless they found evidence that comprehensive income is associated with stock returns. Similar results were obtained by Goncharov and Hodgson (2011) who, based on their research on European capital markets, found that comprehensive income and other comprehensive income elements are connected with price, but not as much as traditional net income. Chambers, Linsmeier, Shakespeare and Sougiannis (2007) found from their sample based on S\&P 500 companies that elements of other comprehensive income affect pricing and returns.

Kanagaretnam, Mathieu and Shehata (2009) showed that comprehensive income explains stock price better than net income, as some elements of comprehensive income (unrealized gains and losses on AFS securities and cash-flow hedges) are significantly correlated with stock prices. Cahan, Courtenay, Gronewoller and Upton (2000) using the New Zealand example, showed that comprehensive income is more value-related than net income. More recent research on that example (Khan, Bradbury and Courtenay, 2017) revealed that there is an association between returns and comprehensive income, which is stronger than the association between net income and returns.

Biddle and Choi (2006) suggested that a comprehensive definition of income provides greater decision usefulness, as well as being correlated with the stock price. Gazzola and Amelio (2014a) concluded that Czech public-listed companies showing comprehensive income provided more (than net income) information about their financial results and effectiveness of the company. In other research (Gazzola \& Amelio, 2014b), they proved that in a period of crisis, comprehensive income has a higher information value than the traditional net income. Yousefi, Ahmad and Embong (2017) found that elements of other comprehensive income are value relevant and positively associated with the stock price.

The research concluded with Romanian companies, in which Mironiuc and Huian (2016) demonstrated a correlation between stock price and earnings measured by both net income and comprehensive income. 
On the other hand, another study on the Romanian market by Păşcan (2014) showed that the net income association with stock price is stronger than the comprehensive income association, which means that comprehensive income is not more value relevant than net income. Some researchers also could not find evidence for the association between comprehensive income and returns. O'Hanlon and Pope (1999) could not prove that elements of other comprehensive income are significantly associated with accounting cash flows. Another study on the Iranian stock exchange (Dastgir \& Velashani, 2008) could not confirm that comprehensive income is superior to net income for performance evaluation based on the stock returns, and could not find evidence that comprehensive income adjustments improve the ability to reflect firm performance. Rusdiyanto and Narsa (2019) in their research based on banking companies listed on the Indonesian stock exchange found no evidence of comprehensive income effects on stock prices.

Previous research on Polish context which considered the correlation between comprehensive income and the stock price was carried out by A Sajnóg (2018), who checked if comprehensive income is correlated with market value more than net income, but the results were not statistically significant. The more research results by Sajnóg (2020) on the Warsaw Stock Exchange example have shown that there is a statistically important positive correlation between comprehensive income and market value, which is not very strong.

Other topics associated with this article, such as predictive power of comprehensive income on the Polish example, were researched by Bareja, Giedroyć and Wrzosek (2019), who showed that elements of other comprehensive income do not have a statistically significant influence on future cash flow and future net income. Nevertheless, it was found that net income, which is an element of comprehensive income has significant predictive power. In that research, comprehensive income has the distribution of net income which is almost the same as the distribution of comprehensive income, which means that comprehensive income should have predictive power, just like net income.

Based on previous studies, as well as theoretical aspects of comprehensive income, the author intended to test the following hypotheses:

$\mathrm{H} 1$ : There is a relation between comprehensive income and market returns.

$\mathrm{H} 2$ : Comprehensive income is related to and affects the stock price.

\section{Sample and data collection}

The research took into consideration companies from the energy sector listed on the Warsaw Stock Exchange (companies included in the WIG-Energia index). The energy sector is considered stable, although in the researched period write-offs had a significant influence on the companies' results (Lipski, 2016). The research included elements recognized in other comprehensive income, The examples of elements of other comprehensive income reported by researched companies are as follows (names vary): 
- actuarial gains/losses,

- re-measurements of defined benefit plans,

- measurement of hedging instruments,

- foreign exchange differences from translation of foreign entities,

- share in other comprehensive income of joint ventures,

- valuation of debt financial instruments,

- others.

This provides a relevant example for research for comprehensive income research.

There are 11 companies in WIG-Energia. Some of them could not be included in the research, thus six companies were excluded from the sample. The main business area of two companies is outside of Poland (CEZ, INTERAOLT), and because the author wanted to focus on the Polish market, they were not taken into consideration. Four companies were listed on the stock market long enough in the period of research (ENERGA, ZEPAK, INTERAOLT and MLSYSTEM), Whereas BEDZIN was also excluded from the research because the company had not included a Comprehensive income statement in its financial reports before 2014.

The research sample was built from the financial data of five WIG-Energia companies: PGE, Tauron, ENEA, Kogeneracja, and Polenergia. To conclude, research addressed financial data like comprehensive income, rate of return and equity capitalization, and data were collected by the author from annual reports (comprehensive income), the Notoria database (equity book value, market capitalization, amount of stock issued) and the website stooq.pl (dividends and stock prices, from which nominal rate of return in periods was calculated).

The timeframe for research was set for the period 2010-2019 (for Tauron who has been listed since June 2010, the author took into consideration the results for 2011-2019). All data were collected for the fiscal year.

It was difficult to determine in which period earnings and returns should be cumulated. When the tax year equals the calendar year, the results are considered for the period from 1st January to the end of December, so they should affect the results in this period. First assumptions about results could be anticipated in interim announcements in the second half of the year. The first final announcement can be made in March/April of the next year before the publication of the financial statement for the year. Investors can anticipate the value of shares earlier. Previous research varied in the assumptions taken, whereas the author assumed that in the long term, earnings are connected with returns in the associated period.

\section{Research methodology}

The article aimed to check if reported net income influences the market rate of return and the stock price. The author wanted to ascertain if there is a correlation between comprehensive and stock price, as well as to check if the market reacts to reported 
accounting information from financial statements through market returns. The theoretical concept is based on studies by Easton and Harris (1991), Ohlson (1989), as well as Ball and Brown (1968), who described that influence in their research and articles. To check the correlation between earnings and stock price, the author conducted empirical research based on the tools and statistical methods developed by Strong (1993). This model, to the best of the author's knowledge has not been used before with comprehensive income reported on the Polish example.

Previous studies classified earnings as net income. The implementation of IAS 1, has extended, from an accounting point of view, the perception of financial performance of the business from net income to comprehensive income.

To check if comprehensive income is associated with stock price, the author used the value relevance model based on Kanagaretman, Mathieu, and Shehata (2009).

There are many methods of stock valuation. According to Ohlson's (1989) second extreme valuation model, the company simply trades at market value equal to book value. This refers to the clean surplus concept, which in a simplified version means that earnings are the difference in book value between periods. Strong (1993) assumed the company trades at the market-to-book ratio, which indicates that:

\section{Equation 1}

$$
V_{j t}=\theta B_{j t},
$$

where: $V_{j t}$ - equity market capitalization of the company, $\Theta$ - price/equity book value ratio, $B$ - the equity book value.

Based on the above, it is possible to assume that the rate of return is indicated by the change in equity book value in the period, which can be explained by comprehensive income. This results in an equation that relates returns to earnings levels:

\section{Equation 2}

$$
R_{j t}=\frac{V_{j t}-V_{j t-1}}{V_{j t-1}} \theta \frac{E_{j t}}{V_{j t-1}},
$$

where: $R_{j t}$ - rate of return of company $j$ at the end of period $t, V_{j t}$ - equity market capitalization of company $j$ at the end of period $t, V_{j t-1}$ - equity market capitalization of company $j$ at the end of period $t-1$ (beginning of period $t$ ), $E_{j t}$ - comprehensive income (reported earnings on clean surplus basis) of company $j$ in period $t$.

This equation models earnings as a transitory process (Strong, 1993). Using this assumption, regression can be created: 


\section{Equation 3}

$$
R_{j t}=a+b \frac{E_{j t}}{V_{j t-1}}+u_{j t},
$$

where: $R_{j t}$ - rate of return of company $j$ at the end of period $t, V_{j t-1}$ - equity market capitalization of company $j$ at the end of period $t-1$ (beginning of period $t$ ), $E_{j t}$ - comprehensive income (reported earnings on clean surplus basis) of company $j$ in period $t$.

To check the direct association between stock price and comprehensive income, the author carried out research using the Ohlson (1995) valuation model, which shows the investor's company value as a function of the book value and residual earnings. This model is described in equation 4 (Kanagaretman et al., 2009):

\section{Equation 4}

$$
V_{j t}=\beta_{0}+\beta_{1} B_{j t}+\beta_{2} E_{j t}+\varepsilon_{j t},
$$

where: $V_{j t}$ - equity market capitalization of company $j$ at the end of period $t, B_{j t}-$ book value of company $j$ at the end of period $t, E_{j t}$ - comprehensive income of company $j$ in period $t$.

According to this model, market capitalization equals the function of book value at that time and abnormal or residual earnings. Ohlson assumed that earnings capture all changes in equity (in clean surplus accounting).

Kanagaretman, Mathieu and Shehata (2009) created a value relevance model considering net income and elements of other comprehensive income. Aggregate comprehensive income was also tested. Due to the aim of the research, which implies informative power of comprehensive income as general, an empirical model described by Equation 5 was created.

\section{Equation 5}

$$
P_{j t}=\beta+\beta B_{-} S_{j t}+\beta E_{-} S_{j t}+\varepsilon_{j t},
$$

where: $P_{j t}$ - price per share of company $j$ at the end of period $t, B S_{j t}-$ book value of company $j$ at the end of period $t$ per share, $E_{-} S_{j t}-$ comprehensive income of company $j$ in period $t$ per share.

\section{Results and discussion}

The descriptive statistics for sample data are shown in Table 1, where the amounts for comprehensive income market capitalization and book value are in billions PLN. The number of shares was also considered (with variation due to the issuance of new shares). The rate of return was calculated with dividends included. 
Table 1. Descriptive statistics for sample data

\begin{tabular}{|l|l|l|l|l|l|l|l|l|}
\hline Variable & \multicolumn{1}{|c|}{ Mean } & $\begin{array}{c}\text { Standard } \\
\text { Error }\end{array}$ & \multicolumn{1}{|c|}{ Median } & $\begin{array}{c}\text { Standard } \\
\text { Deviation }\end{array}$ & $\begin{array}{c}\text { Sample } \\
\text { Variance }\end{array}$ & \multicolumn{1}{|c|}{ Min } & Max & $\mathrm{n}$ \\
\hline$E$ & 0.6894 & 0.2144 & 0.1750 & 1.5752 & 2.4812 & -4.4210 & 4.9856 & 54 \\
\hline$V$ & 8.7700 & 1.5551 & 4.6792 & 11.4273 & 130.5839 & 0.4040 & 42.3080 & 54 \\
\hline$B$ & 14.7030 & 2.2193 & 11.4695 & 15.5351 & 241.3383 & 0.3032 & 46.7270 & 49 \\
\hline$R$ & -0.0310 & 0.0378 & -0.0619 & 0.2648 & 0.0701 & -0.5971 & 0.6872 & 49 \\
\hline$P$ & 26.2700 & 3.5615 & 18.8890 & 24.9302 & 621.5146 & 1.6400 & 109.9000 & 49 \\
\hline
\end{tabular}

$E$ - comprehensive income, $V$ - market capitalization, $B$ - book value, $R$ - rate of return, $P$ - price per share

Source: own work.

To obtain all necessary regression analysis variables, the data was transformed. All the variables are shown in Table 2.

Table 2. Descriptive statistics for research data

\begin{tabular}{|l|l|l|l|l|l|l|l|l|}
\hline Variable & \multicolumn{1}{|c|}{ Mean } & $\begin{array}{c}\text { Standard } \\
\text { Error }\end{array}$ & Median & $\begin{array}{c}\text { Standard } \\
\text { Deviation }\end{array}$ & $\begin{array}{c}\text { Sample } \\
\text { Variance }\end{array}$ & \multicolumn{1}{|c|}{ Min } & \multicolumn{1}{c|}{ Max } & $\mathrm{n}$ \\
\hline$E_{j t} / V_{j t-1}$ & 0.0756 & 0.0147 & 0.0978 & 0.1026 & 0.0105 & -0.2423 & 0.2781 & 49 \\
\hline$B \_S$ & 35.0269 & 4.0112 & 24.7388 & 28.0779 & 788.3701 & 8.9198 & 104.480 & 49 \\
\hline$E \_S$ & 2.1494 & 0.4265 & 1.5186 & 2.9852 & 8.9113 & -2.4235 & 10.6130 & 49 \\
\hline
\end{tabular}

$E$ - comprehensive income of company $j$ in period $t, V$ - market capitalization of company $j$ at the end of period $t-1, B \_S$ - book value per share, $E \_S$ - comprehensive income per share

Source: own work.

The relation between returns and comprehensive income, which is the object of the first hypothesis was tested by regression based on Equation 3. The results of the regression analysis of the relation between returns and comprehensive income divided by market capitalization (from the beginning of the period) showed that there is an average (0.398) correlation between those variables. The adjusted $\mathrm{R}^{\wedge} 2$ of that model is 0.140499683 . The coefficient of $E_{j t} / V_{j t-1}$ is approximately 1.03 and is significant on a 0.01 level.

The second hypothesis is the relation between comprehensive income and stock price. To determine if comprehensive income is associated and affects stock price, the value relevance model was applied, and the correlation between variables was analysed. The results are presented in Table 4. 
Table 3. Tests of relations between market returns and comprehensive income

\begin{tabular}{|l|l|l|}
\hline \multicolumn{1}{|c|}{ Variable } & \multicolumn{1}{c|}{ Coefficient } & \multicolumn{1}{c|}{ t stat } \\
\hline Intercept & -0.10932018 & $-2.5003^{* *}$ \\
\hline$E_{j i} / V_{j t-1}$ & 1.026891091 & $2.97429^{* * *}$ \\
\hline No of observations & 49 & \\
\hline $\mathrm{R}$ & 0.398002438 & \\
\hline $\mathrm{R}^{\wedge} 2$ & 0.158405940 & \\
\hline Adjusted $\mathrm{R}^{\wedge} 2$ & 0.140499683 & \\
\hline $\mathrm{F}$ value & $8.8464018^{* * *}$ & \\
\hline
\end{tabular}

$* *$ p-value $<0.05$

$* * *$ p-value $<0.01$

Source: own work.

Results show that there is a relation between comprehensive income and stock returns. The results correspond with the previous research based on this model (Strong, 1993) as well as the results obtained using the value relevance model (Kanagaretnam et al., 2009).

Table 4. Correlation matrix

\begin{tabular}{|l|l|l|l|}
\hline \multicolumn{1}{|c|}{$P$} & \multicolumn{1}{|c|}{$B \_S$} & \multicolumn{1}{c|}{$E \_S$} & \\
\hline 1 & 0.803686 & 0.804329 & $P$ \\
\hline & 1 & 0.736776 & $B \_S$ \\
\hline & & 1 & $E \_S$ \\
\hline
\end{tabular}

Source: own work.

There is a strong correlation between price and comprehensive income. A similar correlation occurs between book value and price, which means that both variables are strongly associated with the stock price. To determinate the association between the variables, the value relevance model was used. The regression based on Equation 5 was created:

Table 5. Tests of association between book value, comprehensive income and stock price

\begin{tabular}{|l|l|l|}
\hline \multicolumn{1}{|c|}{ Variable } & \multicolumn{1}{c|}{ Coefficient } & \multicolumn{1}{c|}{ t stat } \\
\hline Intercept & 3.582982343 & 1.190576 \\
\hline$E \_S$ & 3.876274055 & $4.210123^{* * *}$ \\
\hline$B \_S$ & 0.409949223 & $4.187973^{* * *}$ \\
\hline No of observations & 49 & \\
\hline $\mathrm{R}$ & 0.862786848 & \\
\hline $\mathrm{R}^{\wedge} 2$ & 0.744401145 & \\
\hline Adjusted $\mathrm{R}^{\wedge} 2$ & 0.733288151 & \\
\hline F value & $66.98475367^{* * *}$ & \\
\hline
\end{tabular}

$$
* * * \text { p-value }<0.01
$$

Source: own work. 
The built regression model is well-fitted on the example data. The adjusted $\mathrm{R}^{\wedge} 2$ equals 0.733 , meaning that it has a satisfactory explanatory value. Both book value and comprehensive income coefficient are statistically significant on a $1 \%$ level. The results of the analysis prove that comprehensive income is associated with and affects stock price. The comprehensive income coefficient was estimated at approximately 3.88. The results of the regression analysis correspond with the previous research results based on other data sample from different markets.

\section{Conclusion}

The use of comprehensive income in financial analysis has both its opponents as well as supporters. The opponents point out that other comprehensive income components include non-operational and not permanent income concepts, therefore they do not show the performance of a company. On the other hand, comprehensive income proponents say that the inclusion of items which potentially can be relevant, provides more information for financial statement users.

Based on research provided in this article, one can assume that comprehensive income and returns of stocks are connected, and that comprehensive income is related to the stock price in the energy sector.

The results of this article are in line with previous research. As with most previous studies, it shows that there is an association between stock price and earnings when earnings were described by comprehensive income or net income. According to many researchers, net income (which is an element of comprehensive income) influences stock price. Numerous previous studies compared net income with comprehensive income. The results vary depending on methodology and researched companies/markets, but generally these results confirm the author's conclusions, which prove that comprehensive income is associated with the stock price. The results of association between comprehensive income and returns are also similar to those previously obtained. The returns are not as strongly associated with comprehensive income, as the association between comprehensive income and stock price, nevertheless there is an association between those categories.

Future research should include more companies from different sectors. This research was limited to only one energy sector. A longer period can also be applied, as well as other statistical methods.

\section{References}

Arkan, T. (2016). The importance of financial ratios in predicting stock price trends: A case study in emerging markets. Finanse, Rynki Finansowe, Ubezpieczenia, (79).

Ball, R., \& Brown, P. (1968). An empirical evaluation of accounting income numbers. Journal of Accounting Research, 6(2), 159-178.

Bareja, K., Giedroyć, M., \& Wrzosek, M. (2019). The predictive power of comprehensive income in Polish companies listed on the Warsaw Stock Exchange. Zeszyty Teoretyczne Rachunkowości, (161). 
Bek-Gaik, B. (2013). Sprawozdawczy wymiar rachunku wyników w warunkach globalnego rynku. Łódź: Wydawnictwo Uniwersytetu Łódzkiego.

Biddle, G. C., \& Choi, J. (2006). Is comprehensive income useful? Journal of Contemporary Accounting \& Economics, 2(1), 1-32.

Black, F. (1980). The magic in earnings: Economic earnings versus accounting earnings. Financial Analysts Journal, 36(6), 19-24.

Cahan, S., Courtenay, S., Gronewoller, P., \& Upton, D. (2000). Value relevance of mandated comprehensive income disclosures. Journal of Business Finance \& Accounting, 27(9) \&(10).

Chambers, D., Linsmeier, T. J., Shakespeare, C., \& Sougiannis, T. (2007). An evaluation of SFAS No. 130 comprehensive income disclosures. Review of Accounting Studies, 12(4), 557-593.

Copeland, T. E., Weston, J. F., \& Shastri, K. (2014). Financial theory and corporate policy. Harlow, Essex: Pearson.

Dastgir, M., \& Velashani, A. S. (2008), Comprehensive income and net income as measures of firm performance: Some evidence for scale effect, European Journal of Economics, Finance and Administrative Sciences, (12), 123-133.

Dhaliwal, D., Subramanyam, K. R., \& Trezevant, R. (1999). Is comprehensive income superior to net income as a measure of firm performance? Journal of Accounting and Economics, (26).

Easton, P., \& Harris, T. (1991). Earnings As an Explanatory Variable for Returns. Journal of Accounting Research, 29(1), 19-36.

FASB Concepts Statement No. 6, Elements of Financial Statements. (1985).

Frendzel, M., \& Szychta, A. (2014). Comprehensive income reporting: Empirical evidence from the Warsaw Stock Exchange. Social Sciences, (82).

Gazzola, P., \& Amelio, S. (2014a). Is total comprehensive income or net income better for the evaluation of companies' financial performance? Central European Review of Economic Issues -Ekonomická Revue, (17), 39-51. doi.10.7327/cerei.2014.03.04

Gazzola, P., \& Amelio, S. (2014b) The impact of comprehensive income on the financial ratios in a period of crises. Procedia Economics and Finance, 12, 174-183.

Goncharov, I., \& Hodgson, A. (2011). Measuring and reporting income in Europe. Journal of International Accounting Research, (10), 27-59.

Har, W. P., \& Ghafar, M. A. (2015). The impact of accounting earnings on stock returns: The case of Malaysia's plantation industry. International Journal of Biometrics, (10), 155.

International Accounting Standards Board. (2020). International financial reporting standards (IFRS's): Including international accounting standards (IAS's) and interpretations. London: International Accounting Standards Board.

Isidro, H., \& Dias, J. G. (2017). Earnings quality and the heterogeneous relation between earnings and stock returns. Rev Quant Finan Acc., (49), 1143-1165.

Kanagaretnam, K., Mathieu, R., \& Shehata, M. (2009). Usefulness of comprehensive income reporting in Canada. Journal of Accounting and Public Policy, 28(4), 349-365.

Khan, S., Bradbury, M. E., \& Courtenay, S. (2017). Value relevance of comprehensive income. Australian Accounting Review, 28(2), 279-287. doi.10.1111/auar.12181

Lev, B. (1989). On the usefulness of earnings and earnings research — lessons and directions from two decades of empirical research. Journal of Accounting Research, (27), 153-192.

Lipe, R. (1990). The relation between stock returns and accounting earnings given alternative information. The Accounting Review, 65(1), 49-71

Lipski, M. (2016). Wyzwania sektora energetycznego w Polsce z perspektywy akcjonariuszy. Zeszyty Naukowe PWSZ w Ptocku. Nauki Ekonomiczne, 1(23), 269-279.

McConnell, C. R., Brue, S. L., \& Flynn, S. M. (2009). Economics: Principles, problems, and policies. Boston: McGraw-Hill Irwin.

Mironiuc, M., \& Huian, M. (2016). Study of the congruence between accounting numbers and stock market variables through comprehensive income: Empirical evidence for Romanian companies quoted on the regulated market. Journal of Accounting and Management Information Systems, (15). 
Newberry, S. (2003). Reporting performance: Comprehensive income and its components, Abacus, 39(3), p. 327.

O'Hanlon, J., \& Pope, P. (1999). The value relevance of UK dirty surplus accounting flows. British Accounting Review, (31), 459-482.

Ohlson, J. (1989). Accounting earnings, book value, and dividends: The theory of the clean surplus equation (part I) (Working Paper).

Ohlson, J. (1995). Earnings, book values, and dividends in equity valuation. Contemporary Accounting Research, 11(2), 661-687.

Păşcan, I. D. (2014). Does comprehensive income tell us more about an entity's performance compared to net income? Study on Romanian listed entities. Procedia Economics and Finance, 15.

Poniatowska, L. (2013). Wpływ wyceny bilansowej na definiowanie i pomiar wyniku finansowego. Studia i Prace Kolegium Zarządzania i Finansów. Zeszyt Naukowy SGH w Warszawie, (130), 113-130.

Rówińska, M. (2019). Dylematy wokół wykorzystania sprawozdania z całkowitych dochodów do oceny sytuacji finansowej przedsiębiorstw. Zeszyty Naukowe SGGW w Warszawie. Polityki Europejskie, Finanse i Marketing, 21(70), 211-219.

Rusdiyanto, R., \& Narsa, I. M., (2019). The effects of earnings volatility, net income and comprehensive income on stock prices on banking companies on the Indonesia Stock Exchange. International Review of Management and Marketing, (9), 18-24.

Sajnóg, A., (2018). Wynik całkowity i wynik finansowy netto w perspektywie wartości rynkowej spółek z indeksu WIG30, Zeszyty Teoretyczne Rachunkowości, 100(156).

Sajnóg, A. (2020). Wynik calkowity - jakość i użyteczność w procesie podejmowania decyzji inwestycyjnych. Łódź: Wydawnictwo Uniwersytetu Łódzkiego.

Strong, N. (1993). The relation between returns and earnings: Evidence for the UK. Accounting and Business Research, 24(93), 69-77.

Szyszka, A. (2002). Wpływ ogłoszeń kwartalnych raportów finansowych na kursy akcji notowanych na GPW, Nasz rynek kapitalowy, 1(133).

Wang, Y., Buijink, W., \& Eken, R. (2006). The value relevance of dirty surplus accounting flows in The Netherlands. The International Journal of Accounting, 41(4), 387-405.

Yousefi, N. M., Ahmad, A., \& Embong, Z. (2017). Value relevance of other comprehensive income. Asian Journal of Accounting and Governance, (8).

\section{WYNIK CAŁKOWITY A CENA AKCJI NA PRZYKŁADZIE SPÓŁEK Z BRANŻY ENERGETYCZNEJ}

Streszczenie: Wyniki finansowe są głównym źródłem informacji dla inwestorów giełdowych. Rada Międzynarodowych Standardów Rachunkowości zmieniła podstawowe zasady dotyczące oceny działalności przedsiębiorstwa, przyjmując wynik całkowity, a nie zysk netto, jako podstawową kategorię oceniającą efektywność prowadzonej działalności. Przedmiotem dotychczasowych badań pod kątem przydatności wyników finansowych do analizy finansowej oraz powiązania tych wyników ze stopą zwrotu oraz ceną akcji był zysk/strata netto. Wyniki tych badań nie są jednak spójne. Wyniki całkowite nie były szeroko analizowane w takim aspekcie. Artykuł poświęcony jest analizie zależności pomiędzy wynikiem całkowitym a ceną akcji spółek energetycznych notowanych na Giełdzie Papierów Wartościowych w Warszawie w latach 2010-2019. Autor przedstawił aspekty teoretyczne oraz prawne zagadnienia koncepcji dochodu całkowitego oraz zbadał wpływ całkowitych dochodów na cenę akcji i stopy zwrotu, stosując podejście ilościowe.

Słowa kluczowe: wynik całkowity, dochód całkowity, cena akcji, sprawozdanie z całkowitych dochodów, clean surplus. 